\title{
EHMTI-0217. Neurophysiological study of tdcs effects in healthy volunteers
}

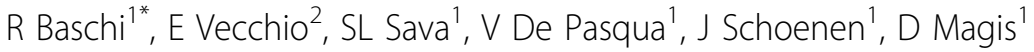 \\ From 4th European Headache and Migraine Trust International Congress: EHMTIC 2014 \\ Copenhagen, Denmark. 18-21 September 2014
}

\section{Introduction}

Transcranial direct current stimulation (tDCS) is a noninvasive neuromodulation technique able to activate (anode) or to inhibit (cathode) the underlying cortex. It could be of interest for the preventive treatment of migraine that is associated with interictal changes in cortical responsivity. To optimize neuromodulation protocols, however, studies of their physiological effects on the normal human brain are necessary.

\section{Aims}

To study short and long-term effects of tDCS with the novel tDCS Cefaly ${ }^{\circ}$ device on visual cortex and DLPFC in healthy volunteers (HV).

\section{Methods}

Nine HV received anodal tDCS over Oz, 9 others anodalF3tDCS with the cathode at Oz: intensity $2 \mathrm{~mA}$, duration 20min. We recorded CHEPS, QST, nBR and VEP at baseline (T0), immediately after tDCS (T1) and after 5 daily stimulations (T5).

\section{Results}

Anodal tDCS over $\mathrm{Oz}$ increased VEP habituation at T1 and even more so at T5 $(\mathrm{p}=0.038)$. It also increased heat pain thresholds $(\mathrm{p}=0.02)$ and CHEPS habituation at T5 $(p=0.035)$, while reducing its latency $(p=0.04)$.The F3 anode-Oz cathode combination only reduced the $\mathrm{nBR}$ sensory threshold at $\mathrm{T} 1(\mathrm{p}=0.039)$.

\section{Conclusions}

Activation the visual cortex with anodal tDCS increases habituation of cortical evoked potentials and heat pain thresholds. This stimulation protocol may thus be of interest in migraine prevention. It also confirms our previous

${ }^{1}$ Department of Neurology, CHR Citadelle, Liege, Belgium

Full list of author information is available at the end of the article finding of an inhibitory connection between visual cortex and pain processing pathways.

No conflict of interest.

\section{Authors' details}

${ }^{1}$ Department of Neurology, CHR Citadelle, Liege, Belgium. ${ }^{2}$ Department of Neuroscience and Sense Organs, University of Bari, Bari, Italy.

Published: 18 September 2014

doi:10.1186/1129-2377-15-S1-E3

Cite this article as: Baschi et al:: EHMTI-0217. Neurophysiological study of tdcs effects in healthy volunteers. The Journal of Headache and Pain 2014 15(Suppl 1):E3.

\section{SpringerOpen $^{\circ}$}

C 2014 Baschi et al; licensee Springer. This is an Open Access article distributed under the terms of the Creative Commons Attribution License (http://creativecommons.org/licenses/by/2.0), which permits unrestricted use, distribution, and reproduction in any medium, provided the original work is properly cited.
Submit your manuscript to a SpringerOpen ${ }^{\circ}$ journal and benefit from:

- Convenient online submission

- Rigorous peer review

- Immediate publication on acceptance

- Open access: articles freely available online

- High visibility within the field

- Retaining the copyright to your article

Submit your next manuscript at $>$ springeropen.com 